warnings issued by the meteorological services of the world appreciated. These warnings are specifically designed to advise aviators, farmers, fishermen, sailors and all those whose work is affected by the weather. The World Meteorological Organization has therefore established the anniversary of the implementation of the Convention of the World Meteorological Organization, March 23, 1950, as World Meteorological Day. The first of these days was celebrated on March 23, 1961. The object is to attract world public interest to the work of the meteorological services and to the assistance they can give. It is also designed to show the need for continuous interchange of meteorological information on a world-wide basis and for meteorological collaboration in other ways, thus demonstrating that the provision of meteorological services in each country is one of the tangible results of day-to-day co-operation between nations. The 109 members of the World Meteorological Organization have been invited to celebrate the World Meteorological Day annually in their country by such means as exhibitions, lectures, visits to national forecasting offices, television and radio coverage.

\section{Experiments on Animals}

A BILL, S3570, providing for the control of experiments on animsls, has recently been introduced in the U.S. Senate. As an aid to its sponsors the secretarygeneral of the Universities Federation for Animal Welfare, Major C. W. Hume, has submitted a report on the present practice in Great Britain (Opinions of British Scientists of Home Office Control of Experiments on Animals. Pp. 8. London: Universities Federation for Animal Welfare, 1961). The report has been based on questions addressed to British scientists who use animals in their experimental work and, with one exception, show that men of science are well content with the present system. They are satisfied that the present system of control and experiment administered by the Home Office does not in any way frustrate experimental work of the highest quality; and they wish to retain Home Office control so that persons without scientific training may not be permitted to experiment on animals without supervision.

\section{Welfare and Care of Laboratory Animals}

THE March issue of the Bulletin of the International Committee on Laboratory Animals is considerably bigger than some of its predecessors, because it contains, in addition to its usual international news items, a list of corresponding members, notes on the visit of the secretary-general, Dr. W. Lane-Petter, to Norway, the Near East and the U.S.S.R., and a long bibliography of papers on various aspects of research, classified according to the experimental animals used, including invertebrates. The Committee is organizing a symposium on "The Problems of Laboratory Animal Disease", which will be held in Czechoslovakia early in September. The Proceedings of the symposium on "Living Animal Material for Biological Research" have now become available. Full information about the many activities of the Laboratory Animals Centre is given in the $L A C$ News letter, published free in January and July and obtainable, as the other publications mentioned above also are, from the director, Dr. W. Lane-Petter, Laboratory Animals' Centre, Medical Research Council Laboratories, Woodmansterne Road, Carshalton, Surrey.

\section{History of Science}

ThIs new annual review of literature, research and. teaching in the history of science is edited by A. C. Crombie (Oxford) and M. A. Hoskin (Cambridge), and published at Cambridge by W. Heffer and Sons, Ltd. There is a board of advisory editors consisting of $G$. Buchdahl, Herbert Butterfield, F. N. L. Poynter and W. P. D. Wightman. The review will contain critical essays surveying recent work on special topics, and others directing attention to problems for research. There will also be sections devoted to book reviews, surveys of articles of special interest published in other journals, and information about research in progress, teaching and other matters relating to the professional development of the subject. The first number will be published early in 1962 .

\section{Queen Victoria Museum and Art Gallery, Launces- ton, Tasmania}

THe recent issues of the Records and the annual reports for 1958-59 and 1959-60 of the Queen Victoria Museum and Art Gallery are complementary to each other. They indicate that museums, in addition to a policy for the conservation of objects, are also centres of scholarly research and do their share in the elucidation of scientific, historical and æsthetic problems. The reports are a record of the vigorous activity of the staff in spite of the usual lack of good exhibition and storage space. In accordance with the general policy of widening the contacts of the Museum with the public, display space has been obtained in the central shopping area of the city. This provides accommodation for a series of fortnightly exhibits of special objects as well as the display of notices regarding the activities of the main Museum. The Records are concerned with the geology of western and northern Tasmania and deal with both the topography and stratigraphy of the area (New Series. No. 12 : Comments on the Cainozoid History of Western Tasmania. By B. Scott. Pp. 10. No. 13: Erosion Surfaces in Western Tasmania. By B. Scott. Pp. 11. Launceston: Queen Victoria Museum and Art Gallery, 1959 and 1960).

\section{Work in the Antarctic during I.G.Y.}

RUSSIAN explorers have been interested in the Antarctic since their first expedition led by F. G. Bellingshausen and M. P. Lazarev during 1819-21. During the International Geophysical Year, when the Antarctic region was studied by a combined effort of twelve nations, the Soviet expedition, centred on the settlement of Mirny, carried out considerable work in this part of the Antaretic continent. In a series of articles published in Priroda certain results of this work are given. Thus B. V. Dubovsky (Priroda, 7, 45; 1960) providss a note on two newly discovered valleys, one called 'The Valley of I.G.Y.' and the other 'Lazarev's trough'. V. D. Novikov (Priroda, 8, 43; 1960) provides an account of the construction of the scientific base Mirny, which was completed during February 1956, and later of eight additional bases. All these bases provided means of systematic and detailed geological, glaciological and meteorological studies, all of which are briefly described by Novikov. In two articles A. G. Dralkin (Priroda, 9, 48; 10, 27 ; 1960) describes the Soviet expedition to the South Pole in 1959 and their meoting of the American contingent of the Polar Amundsen-Scott station. The results of the study of the ice sheet and of the 